\title{
Practice for Second Language Learning: Don't Throw out the Baby with the Bathwater
}

\author{
ROBERT DEKEYSER* \\ University of Maryland
}

Received: 25 July 2010 / Accepted: 10 September 2010

\begin{abstract}
After presenting some of the main arguments against certain narrow concepts of second language practice, this article argues that a broader concept of practice, still focused on form or even forms, but with due attention to form-meaning links and with appropriate sequencing of activities to ensure declarative knowledge first, followed by its proceduralization and (at least partial) automatization, is as relevant as ever. A brief overview is given of the range of activities that fall within this concept, and recommendations are made for adaptation to students' individual and group differences.
\end{abstract}

KEYWORDS: practice, skill acquisition, curriculum design, feedback, individual differences.

\section{RESUMEN}

Tras presentar algunos de los principales argumentos en contra de algunas concepciones restrictivas en relación con la práctica en el aprendizaje de idiomas, se refuerza la validez de la práctica entendida en sentido amplio, centrada en la forma o incluso en las formas, aunque prestando la debida atención a la asociación entre forma y significado, así como tomando en consideración una adecuada secuenciación de actividades con el fin de garantizar la adquisición del conocimiento declarativo primero, seguido de su procedimentalización y automatización (al menos parcial). Se ofrece una breve panorámica de la tipología de actividades incluidas en la propuesta, así como algunas recomendaciones para su adaptación a las diferencias grupales e individuales de alumnos.

PALABRAS CLAVE: práctica, adquisición como destreza, diseño curricular, retroalimentación, diferencias individuales.

*Address for correspondence: Robert DeKeyser. 3215 Jimenez Hall. University of Maryland College Park, MD 20742. USA. E-mail: rdk@umd.edu 


\section{OVERVIEW}

Practice may be a time-tested and commonsensical idea for most teachers and learners, but it has taken a beating in recent decades. Krashen's claimed that "learning does not become acquisition" (1982, p. 83), R. Ellis that "the results [of empirical research] are not very encouraging for practice” (1994), and VanPatten that meaning-based input practice is the driving force rather than systematic production practice because "acquisition happens as a byproduct of comprehension” (2003, p. 26). Perhaps even more prominent these days is Long's view that task-based practice with focus on form should take the place of practice built around forms and that "as many of the problem areas as possible should be handled within otherwise communicative lessons by briefly drawing learners' attention to some items as and when problems arise” (2009, p. 384). From just these few quotations it is clear that the arguments against practice in the "drill and kill” sense of audiolingual methodology are plenty.

Is there still a role then for practice defined as "specific activities in the second language engaged in systematically, deliberately, with the goal of developing knowledge of and skills in the second language” (DeKeyser, 2007a, p. 8)? It would seem that the answer to this question depends on whether the goals of practice in this sense are both worthwhile and achievable, or more precisely more achievable through these means than through others, and I will argue here that the answer to these questions is affirmative, and that the praxis of practice can take many forms, whose effectiveness depends on the students and the context.

\section{REASONS TO REJECT A NARROW CONCEPT OF SYSTEMATIC PRACTICE}

Practice often brings to mind a stereotypical audiolingual classroom where students repeat and transform sentences ad nauseam. It has been argued many times that such drills are of limited use because they do not teach the students to engage in the target behavior of conceptualizing a meaning and expressing it through linguistic means, let alone doing so in creative ways (see e.g. DeKeyser 1998; Krashen, 1982, 1985).

The criticism of systematic practice goes much deeper, however. Some, while not rejecting all focus on form in the way Krashen does, do express doubt about the usefulness of repetitive output practice. A central problem in this respect is that such practice activity does not necessarily make the learners practice the target behavior in the sense of the desired processing of the meaning-to-form links in the way processing instruction does try to teach the processing of form-to-meaning links in comprehending input (cf. VanPatten, 2004; Wong \& VanPatten, 2003). 
Others still go further and reject all teaching and practice focused on forms, because any activity built around specific forms is less conducive to acquisition than real-life tasks that allow for a more incidental focus on form (Long, 1991; Long \& Robinson, 1998), given that during such activities the learner “... is vested in the exchange, so is motivated to learn what is needed and attending to the response, already knows the meaning he or she was trying to express, so has freed up attentional resources to devote to the form of the response, and hears the correct form in close juxtaposition to his or her own, facilitating cognitive comparison" (Long, 2009, p. 385).

Still others do not doubt the usefulness of practice focused on forms, but find it to be of limited use, because it cannot help with the acquisition of new grammar structures, only with automatization of existing knowledge (R. Ellis, 1993).

\section{REASONS TO EMBRACE A BROAD CONCEPT OF SYSTEMATIC PRACTICE}

One should think carefully, however, before concluding that any systematic practice of forms (whether in input or output) is useless. First of all, skill in the use of forms beyond mere familiarity with them is certainly a goal of language teaching, and there is no reason to assume that skill acquisition theory, which stresses the role of declarative knowledge in the development of procedural and eventually largely automatized knowledge, and which has been applied to a variety of cognitive domains (see e.g. Anderson and Lebiere, 1998; Anderson, Bothell, Byrne, Douglass, Lebiere, \& Qin, 2004), is not applicable to language learning. As DeKeyser (2007b) has argued, findings from second language acquisition theory are more compatible with this viewpoint than is often claimed, and much of the misunderstanding on this point is based on a very narrow interpretation of 'one kind of knowledge turning into another' rather than one kind of knowledge playing a causal role in the development of the other (DeKeyser, 2009; DeKeyser \& Criado-Sánchez, in press-a).

In other words, with increased practice and proficiency, it is not just linguistic representations that change, but also the skills for using them (Kroll \& Linck, 2007). Retrieval of knowledge in the course of language processing is a complex skill that requires much practice, and the concept applies to the lexicon as well as to grammar, and regardless of whether one sees the process of automatization more as an increasingly fluid use of rules or as the gradual process of instance retrieval substituting more and more for rule use, as Kroll and Linck seem to do, following Logan's theory of automatization (1988, 1992). Segalowitz (2010) provides a thorough theoretical account of how these processes are at the heart of the development of fluency, and Nation and Newton (2009) make a systematic set of 
recommendations for how to develop fluency in listening and speaking through planning and preparation, repetition, increased time pressure, and restriction to items that are already familiar to the learner.

Even more importantly perhaps, within the field of second language acquisition research, many have argued that a number of elements of any language are hard or impossible to learn through mere exposure and 'practice' in the mere sense of communicating in the target language, because these elements have low frequency or otherwise lack salience, especially where form-meaning mapping is concerned (e.g. DeKeyser, 2005; Pica, 2009). While input enhancement and explicit teaching of form can remedy this problem in some cases, in others extensive practice is needed to proceduralize the form-meaning mapping for production and/or comprehension. This is the case especially where new semantic distinctions need to be acquired (e.g., aspectual distinctions for verb conjugation in the Romance languages or the + /- specific distinction for the article in English), or where certain meanings or combinations of meanings need to be made explicit in L2 when they are not made explicit by the L1 grammar (e.g., plural marking in English for native speakers of Chinese, Japanese or Korean). Proceduralizing and (at least partially) automatizing such distinctions takes a very large amount of practice.

Nation and Newton (2009) may very well be right, then, when they say that "languagefocused learning should not make up more than 25 percent of the whole range of contact that learners have with the language” (2010, p. 148), depending on the situation, more if students have much meaningful contact with the language outside of the classroom, less if their contact with the language is limited to the classroom, but on the other hand, and as their book makes clear, meaning-focused activities can and should still provide quite a bit of focus on form; what they call fluency development even includes repetition of memorized phrases and sentences.

Of course no degree of teaching and practice in the classroom will lead to 'perfect' knowledge of the language; it would be utterly naïve to expect that, given that even many years of residence in the target environment do not (Abrahamsson \& Hyltenstam, 2009; DeKeyser, Alfi-Shabtay, \& Ravid, 2010; DeKeyser \& Larson-Hall, 2005; Hyltenstam and Abrahamsson, 2003). We agree, therefore, that 'practice does not make perfect,' but only in the sense that it is a necessary, not a sufficient feature of language instruction: "communicative practice (...) is not sufficient to lead learners to a high degree of fluency and accuracy in all aspects of second language acquisition,” but "[w]hen practice is defined as opportunities for meaningful language use (both receptive and productive) and for thoughtful, effortful practice of difficult linguistic features, then the role of practice is clearly beneficial and even essential” (Lightbown, 2000, p. 443). 


\section{SYSTEMATIC PRACTICE IS A HOUSE WITH MANY ROOMS}

It should be clear from the discussion above that the term 'practice,' even 'systematic practice,' encompasses much more than mechanical drills. Even 'drills' in the sense of repetitive production of certain forms is not limited to parroting; Paulston and Bruder (1976) already distinguished between mechanical, meaningful, and communicative drills, and other researchers have made similar distinctions (for discussion see e.g. DeKeyser and CriadoSánchez, in press-b). Communicative drills DO make the learners engage in the target behavior of linking a form with a meaning, and are therefore useful in this basic sense (pace Wong and VanPatten, 2003).

Of course, for both cognitive and affective reasons (embedding structures in more realistic discourse where there is less obvious give-away focus on specific forms and providing more enjoyable tasks with more face validity), teachers should go beyond such narrowly focused practice as soon as possible. Various kinds of role plays or information-gap activities can be chosen in such a way that they make the use of certain problematic forms essential or at least highly likely (cf. Loschky and Bley-Vroman's (1993) concepts of taskessentialness and task-usefulness). With the participation of native speakers such tasks cannot only become a source of realistic practice, but also of corrective feedback of various kinds, in particular recasts.

Finally, at the far end of the spectrum, on the opposite side from drills, are contentbased and task-based teaching, where there is no focus on forms anymore, but where there is still ample opportunity for reactive focus on form (cf. e.g. Long, 2009; Norris, 2009). Such learning contexts are certainly desirable, but it is doubtful to what extent they can be created in early stages of foreign language learning, when the linguistic tools at the learners' disposal for both production and comprehension are still quite limited.

All these forms of practice, while going way beyond 'drill and kill,' but do meet our broader definition of 'systematic practice' and fulfill specific functions in the learning process that mere communicative input and interaction cannot.

\section{ADAPTING PRACTICE TO INDIVIDUALS AND CONTEXTS}

Not all forms of practice will work equally well under all circumstances. Most obviously, perhaps, children will not benefit much from some forms of practice that are ideal for adults. On the one hand, children may be more willing than adults or adolescents to go through the most mechanical and repetitive drills, but we saw above that those are of limited use. Age- 
appropriate role-plays, real-life tasks, or even conversation topics may be hard to come by. On the other hand, if practice can be given the form of a game, children will often be more willing to engage in and stick with the activity than adults (cf. also Cameron, 2001; Muñoz, 2007).

Secondly, culture needs to be taken into account, both in the general sense, and in the sense of school culture and previous experience with teaching and learning. Different societies vary drastically in their emphasis on or tolerance of repetitiveness, memorization, creativity, fun, negative feedback, face-saving, and other ingredients that characterize different practice activities to different extents; this has clear implications for teachers' willingness to adopt different forms of practice and students' willingness to learn from them (see e.g. Duff, 1995; Gorsuch, 2000).

Most importantly, perhaps, the ability to benefit from different types of practice (as from different types of instruction more generally) depends to a large extent on the aptitude of the student. Aptitude is taken here in a broad sense of cognitive aptitudes, 'affective' characteristics such as motivation, attitude, and personality, and even previously acquired knowledge and skills. Robinson (2007), in particular, offers many hypotheses about how certain types of activities draw on specific aptitudes: explicit rule learning relies on a constellation of aptitudes that involves mostly grammatical sensitivity and rote memory; aptitude for focus on form via recasts draws on speed and capacity of phonological working memory; aptitude for incidental learning via oral content on analogical reasoning and ability to inference word meaning; aptitude for incidental learning via written content on speed and capacity of working memory for text.

Teachers need to be sensitive to how they can adapt practice activities to their learners. Even if adaptation to individual (constellations of) aptitudes is hardly possible in the classroom and should perhaps wait for more advanced forms of computer-assisted instruction, adaptation to a given group of learners as a function of age or cultural background is both feasible and indispensable.

\section{FURTHER QUESTIONS}

Many questions remain about what forms of practice are best, and now that the theoretical climate in SLA research is less hostile to the teaching and practicing of form than a decade or two ago, more empirical research is beginning to focus on these issues.

Various questions concern the ideal frequency, immediacy, and nature of corrective feedback, and it has become clear that the picture is complex. Many forms of feedback 
contain both positive and negative evidence, and sometimes it is difficult even to determine whether feedback should be considered implicit or explicit (especially as implicitly given feedback can be registered explicitly by the student; lack of explicit metalanguage is not to be confused with lack of explicit learning, i.e. lack of awareness). Overall, the literature is supportive of recasts, because they provide positive evidence at a time when the learner is maximally receptive to them (Long, 2009; Pica, 2009). The effectiveness of recasts varies, however, depending on the part of language that is at issue, and the previous knowledge, willingness to focus on form, and aptitudes of the students (see in particular Egi, 2007; Mackey, Philp, Egi, Fujii, \& Tatsumi, 2002; Ranta \& Lyster, 2007; Robinson, 2007; Sachs \& Suh, 2007; Sagarra, 2007, Sheen, 2006, 2007; Trofimovich, Ammar, \& Gatbonton, 2007). For excellent recent literature reviews and meta-analyses concerning corrective feedback in general and recasts in particular, see Leeman, 2007; Li, 2010; Long, 2007; Lyster \& Saito, 2010; Russell \& Spada, 2006).

Another big question concerns the distribution of practice over time. It has often been documented in educational psychology that distributing a given amount of practice over larger stretches of time is beneficial (see e.g. Seabrook, Brown, \& Solity, 2005), but Collins, Halter, Lightbown, and Spada (1999) and Serrano (in press) show that there are limits to how far this distribution can go, in the sense that spread over a couple of years may be worse than spread over a couple of months, or even spread over a year worse than spread over a semester.

Not be neglected either is the issue of how initial declarative knowledge is to be imparted to the students. Before students can practice usefully, there needs to be knowledge to be practiced, and the profession has come to realize more and more that traditional presentation of grammar rules is not the only way to achieve that. Even proponents of otherwise very different approaches such as the cognitivists advocating task-based approaches (e.g. Ellis, 2003; Long, 2009) and the socioculturalists advocating socially generated knowledge (e.g. Swain and Lapkin, 1998) can agree that explicit knowledge is best retained when it is offered in answer to questions arising from communicative interaction. How to make this process maximally efficient, however, and how to ensure that such knowledge is encoded is ways that are maximally conducive to transfer to other tasks remains a difficult issue.

Most important of all, however, is the question of how student aptitudes, characteristics of the forms to be acquired, and practice modalities interact to determine learning. As stated above, there is limited evidence already that the effectiveness of various forms of practice and feedback depends both on the learners' aptitudes and the characteristics of the form to be learned, but no research so far has addressed the interaction between all three variables. Furthermore, in the SLA area, no research exists on the interaction of practice with the exact 
nature of students' knowledge in terms of skill acquisition. Such research is not practicable in traditional classroom contexts, but in the computer-assisted context, research involving student modeling and adaptive feedback holds promise in this respect, judging from work in other areas such as algebra, computer science, or physics (cf. Koedinger \& Corbett, 2006; Lesgold, 2003).

At the same time, however, it is important not to lose the classroom out of sight as a potential research site. Not only is classroom research needed to maximize ecological validity; it is also the only practical way of assuring longitudinal research on instructed language learning (Pica, 2009), and the effect of different kinds of teaching and practicing structure is so central to the enterprise of second language instruction that it deserves this kind of attention. This will require, however, that classroom researchers make an effort to design and carry out controlled experimental studies instead of merely descriptive and correlational ones, and at the same time that more psycholinguistically oriented researchers learn to understand the value of a study that is not $100 \%$ controlled, but that deals directly with the processes that matter most to most second language learners and teachers in the most controlled way that is practically feasible.

\section{CONCLUSION}

The acquisition of second language skills requires large amounts of practice, as is the case of any other kind of skill. Mere exposure to or unstructured interaction in the target language is not ideal practice. More systematic activities are needed; this does not mean repetitive manipulation of form, but can take a variety of shapes, from initial communicative drills to role-playing activities, task-based learning, and content-based teaching. Practice, like other aspects of the curriculum, should be adapted to the learners' characteristics and to the teaching context. Research on how to optimize such adaptation can be an intellectually stimulating enterprise for years to come, with an unusually high yield of practically usable findings.

\section{REFERENCES}

Abrahamsson, N., \& Hyltenstam, K. (2009). Age of onset and nativelikeness in a second language: Listener perception versus linguistic scrutiny. Language Learning, 59(2), 249-306.

Anderson, J. R., Bothell, D., Byrne, M. D., Douglass, S., Lebiere, C., \& Qin, Y. (2004). An integrated theory of the mind. Psychological Review, 111(4), 1036-1060.

Anderson, J. R., \& Lebiere, C. (1998). The atomic components of thought. Mahwah, NJ: Lawrence Erlbaum.

Cameron, L. (2001). Teaching languages to young learners. Cambridge, UK: Cambridge University 
Press.

Collins, L., Halter, R. H., Lightbown, P. M., \& Spada, N. (1999). Time and the distribution of time in L2 instruction. TESOL Quarterly, 33(4), 655-680.

DeKeyser, R. M. (1998). Beyond focus on form: Cognitive perspectives on learning and practicing second language grammar. In C. Doughty \& J. Williams (Eds.), Focus on form in classroom second language acquisition (pp. 42-63). New York: Cambridge University Press.

DeKeyser, R. M. (2005). What makes learning second-language grammar difficult? A review of issues. Language Learning, 55(Supplement 1), 1-25.

DeKeyser, R. M. (2007a). Situating the concept of practice. In R. M. DeKeyser (Ed.), Practice in a second language: Perspectives from applied linguistics and cognitive psychology (pp. 1-18). New York: Cambridge University Press.

DeKeyser, R. M. (2007b). Skill acquisition theory. In B. VanPatten \& J. Williams (Eds.), Theories in Second Language Acquisition: An introduction (pp. 97-112). Mahwah, NJ: Erlbaum.

DeKeyser, R. M. (2009). Cognitive-psychological processes in second language learning. In M. Long \& C. Doughty (Eds.), Handbook of Second Language Teaching (pp. 119-138). Oxford, UK: Wiley-Blackwell.

DeKeyser, R. M., Alfi-Shabtay, I., \& Ravid, D. (2010). Cross-linguistic evidence for the nature of age effects in second language acquisition. Applied Psycholinguistics, 31(3), 413-438.

DeKeyser, R. M., \& Criado-Sánchez, R. (in press-a). Automatization, skill acquisition, and practice in second language acquisition. In C. A. Chapelle (Ed.), The Encyclopedia of Applied Linguistics. Oxford, UK: Wiley-Blackwell.

DeKeyser, R. M., \& Criado-Sánchez, R. (in press-b). Practice in second language instruction. In C. A. Chapelle (Ed.), The Encyclopedia of Applied Linguistics. Oxford: Wiley-Blackwell.

DeKeyser, R. M., \& Larson-Hall, J. (2005). What does the critical period really mean? In J. F. Kroll \& A. M. B. de Groot (Eds.), Handbook of Bilingualism: Psycholinguistic Approaches (pp. 89108). Oxford: Oxford University Press.

Duff, P. A. (1995). An ethnography of communication in immersion classrooms in Hungary. TESOL Quarterly, 29, 505-537.

Egi, T. (2007). Recasts, learners' interpretations, and L2 development. In A. Mackey (Ed.), Conversational interaction in second language acquisition (pp. 249-360). New York: Oxford University Press.

Ellis, R. (1993). The structural syllabus and second language acquisition. TESOL Quarterly, 27(1), 91113.

Ellis, R. (1994). The study of second language acquisition. Oxford: Oxford University Press.

Ellis, R. (2003). Task-based language learning and teaching. Oxford, UK: Oxford University Press.

Gorsuch, G. J. (2000). EFL educational policies and educational cultures: Influences on teachers' approval of communicative activities. TESOL Quarterly, 34(4), 675-710.

Hyltenstam, K., \& Abrahamsson, N. (2003). Maturational constraints in second language acquisition. In C. J. Doughty \& M. H. Long (Eds.), Handbook of second language acquisition (pp. 539588). Oxford, UK: Blackwell.

Koedinger, K. R., \& Corbett, A. (2006). Cognitive tutors: Technology bringing learning sciences to the classroom. In R. K. Sawyer (Ed.), The Cambridge Handbook of the Learning Sciences (pp. 61-77). New York: Cambridge University Press.

Krashen, S. D. (1982). Principles and practice in second language acquisition. Englewood Cliffs: Prentice-Hall.

Krashen, S. D. (1985). The input hypothesis. London/New York: Longman.

Kroll, J. F., \& Linck, J. A. (2007). Representation and skill in second language learners and proficient bilinguals. In I. Kecskes \& L. Albertazzi (Eds.), Grammatical gender in the bilingual lexicon: A psycholinguistic approach (pp. 237-269). Dordrecht, The Netherlands: Springer.

Leeman, J. (2007). Feedback in L2 learning: Responding to errors during practice. In R. DeKeyser (Ed.), Practice in a second language. Perspectives from applied linguistics and cognitive psychology (pp. 111-137). New York: Cambridge University Press.

Lesgold, A. (2003). Intelligent tutoring systems. In L. Nadel (Ed.), Encyclopedia of Cognitive Science (Vol. 2, pp. 593-598). London, UK: Macmillan.

Li, S. (2010). The effectiveness of corrective feedback in SLA: A meta-analysis. Language Learning, 
60(2), 309-365.

Lightbown, P. (2000). Classroom SLA research and second language teaching. Applied Linguistics, 21(4), 431-462.

Long, M. (1991). Focus on form: a design feature in language teaching methodology. In K. de Bot, D. Coste, R. Ginsberg \& C. Kramsch (Eds.), Foreign language research in cross-cultural perspective (pp. 39-52). Amsterdam/Philadelphia: John Benjamins.

Long, M. (2007). Problems in SLA. Mahwah, NJ: Erlbaum.

Long, M. (2009). Methodological principles for language teaching. In M. Long \& C. Doughty (Eds.), Handbook of second language teaching (pp. 373-394). Oxford, UK: Wiley-Blackwell.

Loschky, L., \& Bley-Vroman, R. (1993). Grammar and task-based methodology. In G. Crookes \& S. Gass (Eds.), Tasks and language learning: Integrating theory and practice (pp. 122-167). Clevedon, UK: Multilingual Matters.

Long, M. H., \& Robinson, P. (1998). Focus on form: Theory, research, and practice. In C. Doughty \& J. Williams (Eds.), Focus on form in classroom second language acquisition (pp. 15-41). New York: Cambridge University Press.

Lyster, R., \& Saito, K. (2010). Oral feedback in classroom SLA: A meta-analysis. Studies in Second Language Acquisition, 32(2), 265-302.

Mackey, A., Philp, J., Egi, T., Fujii, A., \& Tatsumi, T. (2002). Individual differences in working memory, noticing of interactional feedback and L2 development. In P. Robinson (Ed.), Individual differences and instructed language learning (pp. 181-209). Amsterdam/Philadelphia: Benjamins.

Muñoz, C. (2007). Age differences and their implications for practice. In R. M. DeKeyser (Ed.), Practice in a second language: Perspectives from applied linguistics and cognitive psychology (pp. 229-255). New York: Cambridge University Press.

Nation, I. S. P., \& Newton, J. (2009). Teaching ESL/EFL listening and speaking. London: Routledge.

Norris, J. (2009). Task-based teaching and testing. In M. Long \& C. Doughty (Eds.), The Handbook of Language Teaching (pp. 578-594). Oxford: Wiley-Blackwell.

Paulston, C. B., \& Bruder, M. N. (1976). Teaching English as a second language: Techniques and Procedures. Cambridge, MA: Winthrop.

Pica, T. (2009). Second language acquisition in the instructional environment. In W. Ritchie \& T. Bhatia (Eds.), The New Handbook of Second Language Acquisition (pp. 473-501). Bingley, UK: Emerald.

Ranta, L., \& Lyster, R. (2007). A cognitive approach to improving immersion students' oral language abilities: The Awareness-Practice-Feedback sequence. In R. M. DeKeyser (Ed.), Practice in a second language: Perspectives from Applied Linguistics and Cognitive Psychology (pp. 141160). New York: Cambridge University Press.

Robinson, P. (2007). Aptitudes, abilities, contexts, and practice. In R. M. DeKeyser (Ed.), Practice in a second language. Perspectives from applied linguistics and cognitive psychology (pp. 256286). Cambridge, UK: Cambridge University Press.

Russell, J., \& Spada, N. (2006). The effectiveness of corrective feedback for the acquisition of L2 grammar: A meta-analysis of the research. In J. Norris \& L. Ortega (Eds.), Synthesizing research on language learning and teaching (pp. 133-164). Philadelphia / Amsterdam: John Benjamins.

Sachs, R., \& Suh, B.-R. (2007). Textually enhanced recasts, learner awareness, and L2 outcomes in synchronous computer-mediated interaction. In A. Mackey (Ed.), Conversational interaction in second language acquisition (pp. 197-227). New York: Oxford University Press.

Sagarra, N. (2007). Computer-delivered recasts, working memory, L2 development and modified output. In A. Mackey (Ed.), Conversational interaction and second language acquisition. Oxford, UK: Oxford University Press.

Seabrook, E., Brown, G. D. A., \& Solity, J. E. (2005). Distributed and massed practice: From laboratory to classroom. Applied Cognitive Psychology, 19, 107-122.

Segalowitz, N. (2010). Cognitive bases of second language fluency. New York: Routledge.

Serrano, R. (in press). The time factor in EFL classroom practice. Language Learning, 61(1).

Sheen, Y. (2006). Exploring the Relationship between Characteristics of Recast and Learner Uptake. Language Teaching Research, 10(4), 361-392. 
Sheen, Y. (2007). The effect of focused written corrective feedback and language aptitude on ESL learners' acquisition of articles. TESOL Quarterly, 41(2), 255-283.

Swain, M., \& Lapkin, S. (1998). Interaction and second language learning: Two adolescent French immersion students working together. The Modern Language Journal, 82(3), 320-337.

Trofimovich, P., Ammar, A., \& Gatbonton, E. (2007). How effective are recasts? The role of attention, memory, and analytical ability. In A. Mackey (Ed.), Conversational interaction in second language acquisition (pp. 171-195). New York: Oxford University Press.

VanPatten, B. (2003). From input to output: A teacher's guide to second language acquisition. New York: McGraw-Hill.

VanPatten, B. (2004). Input processing in second language acquisition. In B. VanPatten (Ed.), Processing instruction. Theory, research, and commentary (pp. 5-31). Mahwah, NJ: Erlbaum.

Wong, W., \& VanPatten, B. (2003). The evidence is IN: Drills are OUT. Foreign Language Annals, 36(3), 403-423. 